$\mathrm{A} \int_{\cos } \mathrm{H}$

Article history :

Received : 18.09.2014

Revised : 24.03.2015

Accepted : 10.04.2015
Members of the Research Forum

Associated Authors:

${ }^{1}$ Department of Vegetable Science, College of Horticulture, Halladkari

Farm Hyderabad Road, BIDAR (KARNATAKA) INDIA
Author for correspondence : C.N. HANCHINAMANI Department of Vegetable Science, College of Horticulture, Halladkari Farm Hyderabad Road, BIDAR (KARNATAKA) INDIA

Email : imamjath@gmail.com
THEASIAN JOURNAL OF HORTICULTURE

Volume 10 | Issue 1 | June, 2015 | 49-52

Visit us -www.researchjournal.co.in

\title{
Evaluation of dolichos genotypes (Dolichos lablab L.) under north eastern dry zone of Karnataka
}

\section{K. RAVINAIK ${ }^{1}$, C.N. HANCHINAMANI, M.G. PATIL ${ }^{1}$ AND S.J. IMAMSAHEB ${ }^{1}$}

ABSTRACT : Nine genotypes of dolichos bean were assessed for performance at Main Agriculture Research Station, Raichur. The experiment was laid out by adopting Randomized Block Design with three replications. Highly significant differences were observed in the genotypes for all the characters under study viz., The plant height of dolichos bean genotypes differed significantly with each other at all the growth stages. At all the growth stages, PD-31 showed maximum height $(108.87,185.33$ and $196.27 \mathrm{~cm}$, respectively). Pod yield per plant showed significant difference between genotypes. The number of pods per cluster. Maximum number of pods per cluster was observed in PD-31 (20.27). Pod yield per plant was maximum in PD-31 $(3.27 \mathrm{~kg})$ followed by PD-22 $(3.18 \mathrm{~kg})$ and PD-15 $(3.10 \mathrm{~kg})$, whereas, least pod yield per plant was recorded in PD-20 $(2.39 \mathrm{~kg})$.

KEY WORDS : Dolichos bean, Genotypes

HOW TO CITE THIS ARTICLE : Ravinaik, K., Hanchinamani, C.N., Patil, M.G. and Imamsaheb, S.J. (2015). Evaluation of dolichos genotypes (Dolichos lablab L.) under north eastern dry zone of Karnataka. Asian J. Hort., 10(1) : 49-52. 